\title{
German Classicists and the Hunt for Literary Papyri: Discovering New Materials about a Secret (and Hence Forgotten) Project
}

\author{
Holger Essler, Julius-Maximilians-Universität Würzburg
}

\begin{abstract}
A B STR A C T
The essay focuses on the initiatives of German classicists to acquire papyri in the period predating the Great War (1890-1914). In Berlin, it was Hermann Diels (18481922) and Ulrich von Wilamowitz-Moellendorff (1848-1931) who took the lead in an enterprise that would ultimately result in the founding and enlarging of some fifteen papyrus collections in Germany. Since it was considered counterproductive to reveal one's partners in the Egyptian antiquities market to possible competitors, most of the information was kept secret. Thus, although numerous leading philologists of the time were involved in the project, very few traces remain in their publications, and it was only seventy-five years after its disbandment that its fundamental documents were published. The complete picture may only be reconstructed from long forgotten archives that were rediscovered in the last decades.
\end{abstract}

$\mathrm{n}$ the period predating the Great War, roughly from 1890 to 1914, Berlin was one of the hotspots of classical philology at the time or — as some might argue — of all times. The two protagonists of this case study, Hermann Diels (1848-1922) and Ulrich von Wilamowitz-Moellendorff (1848-1931), are well known among classicists, both through their numerous and well-received writings and through their extensive exchange of letters, major parts of which were published from 1934 onward. ${ }^{1}$ However,

1. On Diels's papers, see Emile de Strycker SJ, “Der Nachlaß von Hermann Diels," Philologus: Zeitschrift für antike Literatur und ihr Nachleben 121 (1977): 137-45. His letters are edited in William M. Calder III, Maximilian Braun, and Dietrich Ehlers, eds., Philology and Philosophy: The Letters of Hermann Diels to Theodor and Heinrich Gomperz (1871-1922) (Hildesheim: Weidmann, 1995); William M. Calder III, Maximilian Braun, and Dietrich Ehlers, eds., "Lieber Prinz": Der Briefwechsel zwischen Hermann Diels und Ulrich von Wilamowitz-Moellendorff(1869-1921) (Hildesheim: Weidmann, 1995); Dietrich Ehlers, ed., Briefwechsel: Hermann Diels, Hermann Usener, Eduard Zeller, 2 vols. (Berlin:

History of Humanities, Volume 5, Number 1. https://doi.org/10.1086/707698

(c) 2020 by Society for the History of the Humanities. All rights reserved. 2379-3163/2020/0501-0011\$10.00 
in all these documents there is hardly a trace to be found of the leading role they played in the founding of an organization that was responsible for the emergence and expansion of around fifteen papyrus collections in Germany. ${ }^{2}$ The race for papyri reflects the GermanEnglish opposition of the time in the area of classics. It was triggered by the rediscovery in the 1890s of an increasing number of classical Greek texts. To describe the situation we may quote from the new edition of Herondas, published in 1891. Its editor, Frederic G. Kenyon (1863-1952), expresses the hope to discover new classical texts: ${ }^{3}$

It is not often that a literary discovery can restore to us, not merely a work or an author hitherto practically unknown, but a species of ancient literature of which no complete specimen has been extant within modern times. The text, however, which is here published, though not itself of first-class literary value, possesses this distinction; and it also serves to reinforce the growing hopes of a considerable extension of the field of known classical literature. Half a century ago scholars might reasonably have despaired of ever adding materially to the number of works of Greek authors already in their hands, and have resigned themselves to knowing the rest only in fragments and isolated quotations. The discoveries of recent years in Egypt have gone far to open up a brighter prospect, and to raise expectations which, it is much to be hoped, will not be disappointed.

In fact, Kenyon played a major role in publishing these new texts: Still in 1891, he published a papyrus containing Aristotle's Constitution of Athens. The book seems to have sold well and reached its third edition within a year. The year 1897 saw the return of Bacchylides, a contemporary of Pindar. Only a few verses of his works had survived in the medieval tradition, but Kenyon could present thirty-nine almost complete columns. ${ }^{4}$ While contributing numerous monographs to the interpretation of the texts

Akademie-Verlag, 1992). A biography of Wilamowitz is in Robert L. Fowler, "Ulrich von WilamowitzMoellendorff," in Classical Scholarship: A Biographical Encyclopaedia, ed. W. W. Briggs and William M. Calder III (New York: Garland, 1990), 489-522. There are numerous (partial) editions of his letters, from H. Dieterich and F. Hiller von Gaertringen's Usener und Wilamowitz: Ein Briefwechsel, 18701905 (Leipzig: Teubner, 1934), to the most recent by William M. Calder III, "Aus dem Freund ein Sohn": Theodor Mommsen und Ulrich von Wilamowitz-Moellendorff, Briefwechsel 1872-1903, 2 vols. (Hildesheim: Weidmann, 2003).

2. Wolfgang Müller attributes a leading role to Berlin with the other institutions following suit: "Papyruskunde," in Das Institut für Griechisch-Römische Altertumskunde: Protokoll der Eröffnungstagung vom 23.-26. Oktober 1955 (Berlin: Deutsche Akademie der Wissenschaften, 1957), 87-93, 91.

3. The quotation is from F. G. Kenyon, ed., Classical Texts from Papyri in the British Museum: Including the Newly Discovered Poems of Herodas (London: British Museum, 1891), 1.

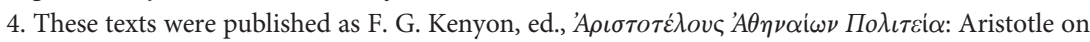
the Constitution of Athens (London: British Museum, 1891), and The Poems of Bacchylides: From a Papyrus in the British Museum (London: British Museum, 1897). 
published in London, ${ }^{5}$ the German philologists did not want to stand back in the race for the primary material. Due to the political and academic situation at the time, their steps, however, were more secret and never officially announced to the public. When in 1996 Oliver Primavesi published his pioneering study "Zur Geschichte des Deutschen Papyruskartells," he started out by summarizing what was known about the Kartell so far:

It is regrettable not only in view of the history of science, but also in the practical papyrological sense that the history of the German Papyrus Cartel is largely unknown: Karl Preisendanz in his standard work on the history of papyrus collections situates the date of the founding of the cartel in 1906 and thus four years too late. . . Ulrich von Wilamowitz-Möllendorff, as we shall see, played a decisive role in the founding of the cartel and as a member of the Berlin Papyrus Commission, must have known the facts well. However, his "Erinnerungen 1848-1914" are of little help, on the contrary: one gains the impression that the Berlin Papyrus Commission was formed solely for the purpose of the publication of Papyri, but not for the purpose which their official designation indicated clearly enough: The acquisition of new literary papyri for Berlin. Nor does Wilamowitz mention the two most important administrative measures with which the Commission sought to promote the papyrus acquisitions of the Berlin Museum: In 1901, it launched the Prussian papyrus project with state funds. In 1902, it instigated the foundation of the Papyrus Cartel in order to put an end to the competition with other German parties that the Prussian papyrus project was facing on the Egyptian papyrus market. ${ }^{6}$

Thanks to Primavesi's research and subsequent studies the basic history of the socalled Deutsches Papyruskartell is now fairly clear: It was active from 1902 to 1914 and made more than 240 purchases of papyri, resulting in an estimated number of 50,000 fragments. However, several questions regarding scholarly forgetting arise from his statement. This case study aims at addressing three of them in particular: (1) Why

5. For the first text alone there was the edition G. Kaibel and U. von Wilamowitz-Moellendorff,

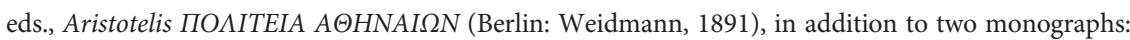

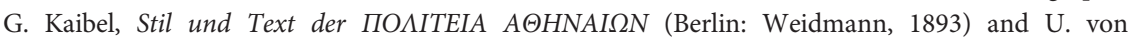
Wilamowitz-Moellendorff, Aristoteles und Athen, 2 vols (Berlin: Weidmann, 1893). Additional studies appeared in the meantime, including, for example, B. Keil, Die solonische Verfassung in Aristoteles Verfassungsgeschichte Athens (Berlin: R. Gaertner, 1892); and Diels went to London to check the original for them (see Kaibel, Stil und Text, iv).

6. Oliver Primavesi, "Zur Geschichte des Deutschen Papyruskartells," Zeitschrift für Papyrologie und Epigraphik 114 (1996): 173-87. Unless otherwise noted, all translations are my own. 
are there virtually no traces of the cartel in the papers and memoirs of the people involved? (2) What is the scholarly significance of this forgotten knowledge? (3) Which factors enabled Primavesi to rediscover and reconstruct major parts of the picture? And, finally, what additional information has become available since Primavesi's study? In conjunction with this final question, I will also draw attention toward the end of this essay to the promise of cataloging and digitization for recovering forgotten knowledge and, thus, revealing instances of forgetting in the history of scholarship.

\section{WHY ARE THERE VIRTUALLY NO TRACES OF THIS ORGANIZATION IN THE PAPERS AND MEMOIRS OF THE PEOPLE INVOLVED?}

It seems obvious to refer to the cartel's secret character in order to explain why the scholars involved avoided mentioning the project. However, this cannot entirely account for the silence. After all, the cartel was not an entirely secret organization. Some members, such as the papyrologist Ulrich Wilcken (1862-1944) in the preface to his edition of papyri from Würzburg and the Bremen collection openly mentioned the role of the cartel in the purchase of papyri. ${ }^{7}$ Moreover, even outside the circle of its fifteen members, consisting of both public institutions and private individuals with their partners and sponsors, the existence of the cartel must have been widely known, if not officially advertised. This can be inferred from the articles of association ( $\mathrm{Sa}$ tzungen) defining the purpose of the cartel to unite the efforts of every German institution and scholar interested in acquiring Greek papyri from Egypt. ${ }^{8}$ Hiding the cartel from potential members would therefore have been counterproductive. Moreover, it would not explain why the cartel was conspicuously absent in the correspondence of Diels and Wilamowitz. For lack of direct statements, their reasons can only be inferred from the overall situation. First of all, both of them - unlike Wilcken-were not direct members of the cartel and thus had no immediate access to its files after it was disbanded. On the other hand, they were part of the commission that directed the project of acquiring papyri for the Berlin Museum, namely, the Preußisches Papyrusunternehmen (Prussian Papyrus Project). This undertaking was, at least in the beginning, intended to be secret, as we shall see. One of the instructions passed on to the German consulate in Cairo, intended to inform the deputy Egyptologist, Ludwig Borchardt (1863-1938) — mainly known for his role in bringing Nefertiti to Berlin — of the scope and intention of the Berlin project, reads as follows:

7. U. Wilcken, ed., Mitteilungen aus der Würzburger Papyrussammlung (Berlin: Verlag der Akademie der Wissenschaften, 1934), and Die Bremer Papyri (Berlin: Verlag der Akademie der Wissenschaften, 1936).

8. The articles are printed in Primavesi, "Zur Geschichte," 183-87; the statement is in $\$ 2$ on 184 and 185 . 
For the systematic acquisition of works of Greek literature preserved on papyrus, the state budget for 1901 granted a sum of 30,000 marks as a first instalment. Due to the necessary secrecy of the planned enterprise, the sum is listed under the general label "For scientific investigations and acquisitions in Egypt." . . . For the beginning of the enterprise, the General Administration of the Royal Museums, in accordance with the two principal representatives of classical philology of the local university, the Secret Government Councilors Dr. von WilamowitzMöllendorff, Dr. Diels, and the Director of the Egyptian Department of the Royal Museums, Professor Dr. Erman, intends to use the services of the scientific attaché at the German Consulate General in Cairo, Dr. Borchardt. ${ }^{9}$

The confidential enclosed letter to the German consul reads:

In regard to all measures concerning this important project Your Excellency will keep in mind that it can only be achieved through prudence and, in particular, through strict secrecy of the plan. ${ }^{10}$

From this project arose the committee at the Berlin Museum, whose members were the aforementioned experts Diels, Wilamowitz-Möllendorff, and Erman, and Richard Schöne (1840-1922), then director of the Royal Museum. The committee met at regular intervals and in the meantime, decisions were made by circulating documents to which the members added their statements in the margin. Minutes and external correspondence were taken care of by the secretary of the museum's Egyptian collection. This helps explain why there was no need for additional letters: most of the documentation related to the Prussian Papyrus Project was filed in the museum-where it was eventually lost in World War II. Furthermore, Berlin left the cartel in 1912 and in the following years adopted a rival policy toward the cartel, which was then led by the director of the Imperial library at Strasbourg. Thus the files of the cartel were, and still are, kept there. After the Great War, Diels and Wilamowitz - or any other German scholar - would not have access to these documents, and they had no reason to mention a competing organization and bring back bitter memories among their German colleagues. Apart from practical difficulties, some sort of self-censorship might have been at stake as well: in view of inflation and economic crisis the 1920s were arguably not the best time to boast the financial means and prestige of prewar German scholarship. ${ }^{11}$

9. Translation from a copy of the letter dated April 25, 1901, kept in R 138392, Politisches Archiv, Auswärtiges Amt, Berlin.

10. Translation from a copy of the letter dated April 30, 1901, kept in R 138392, Politisches Archiv, Auswärtiges Amt, Berlin.

11. In monographs and journals of the time, references to the exploding cost of printing abound. To mitigate the difficulties, the Notgemeinschaft der Deutschen Wissenschaft (Emergency Association of German Science) was founded on October 30, 1920, in order to facilitate raising and distributing funds. 
If the cartel was not an entirely secret organization, how then can it be explained that Carl Preisendanz (1883-1968) got even the starting date wrong in his 1933 historiographical piece? After all, at the time of writing, the cartel had been disbanded for barely nineteen years, and many scholars involved were still alive. ${ }^{12}$ It seems fair to assume that Preisendanz's source was a scholar who had joined later and was therefore not fully aware of the organization's early history. The obvious candidate would be somebody at the Heidelberg University library, over which Preisendanz would preside from 1935 onward. The library had joined the cartel in 1905 but did not acquire any papyri before 1912. However, from the papers of Karl Kalbfleisch's (1868-1946), who was then professor of classics at Gießen, it appears that Preisendanz, in writing his monograph, consulted Kalbfleisch as a source on the cartel's history. ${ }^{13}$ Kalbfleisch had joined the cartel in 1906, the year reported by Preisendanz.

\section{WHAT IS THE SCHOLARLY IMPORTANCE OF THIS FORGOTTEN KNOWLEDGE?}

To what extent does the very brief history outlined above impact present-day research, apart from contributing to the historiography of papyrology? What, in other words, is the relevance of this forgotten knowledge? Most of the information regarding the purchase of papyri never made it into the edition. Although it would have been interesting to know more about the prices paid for papyrological artifacts at the time, this information is not of vital importance. It is, first and foremost, provenance-related information that can yield promising new insights. Since copies of literary texts very rarely bear internal clues about the place of their production, it becomes virtually impossible to reconstruct their history, if we lack external data. Therefore, the risk of forgettingon yet another level - is rather high in this case. Furthermore, complete information about provenance makes it easier to detect separated fragments and to link literary texts with the history of the site reconstructed from documents. It also enables research about the history of the book, about production and circulation of books and texts in different places and times, about the history of writing, and so forth. This was clear to the founders of the cartel, and strict orders were given to the agents in Egypt that the dealer provide complete information about the location of the find and record it meticulously. It goes without saying that this was not in the dealers' interest, given that a productive site might attract other excavators, not least the Prussian Papyrus Project, which was always looking for promising sites. Taking into account that dealers might

12. Karl Preisendanz, Papyrusfunde und Papyrusforschung (Leipzig: Karl W. Hiersemann, 1933), $210-11$.

13. The letters from 1931 are kept in Nachlass Karl Kalbfleisch 8, Universitätsbibliothek Gießen. 
have given imprecise or misleading indications, it is therefore important to investigate all objects that went through their hands. In turn, European buyers had no interest in revealing their preferred dealers and tried to keep potential competitors at a distance. Consequently, in those days publications tended to be selective in their information about the place of origin and as a rule did not mention the dealer from whom the papyrus was acquired. All this information can be inferred from the documentation stored by the cartel - as far as it is preserved. We should add that the history of the antiquities trade in Egypt has become the subject of investigation in its own right. ${ }^{14}$

The cartel was at the center of conflicting interests in classics. In German internal affairs, the competition between different nations to build their own collections of primary material translated to a conflict between centralizing and distributing the papyri thus acquired. The conflict had some echoes in the press, notably the Münchner Allgemeine Zeitung, but also in the exchange of notes verbales between the embassies of German states. ${ }^{15}$ This points to a peculiarity of the cartel material: while most published correspondence by classics scholars was exchanged between friendly or closeknit colleagues, the character of the cartel gave rise to various conflicts of interest and thus provides insight into academic politics from a different perspective.

\section{HOW DID PRIMAVESI MAKE HIS REDISCOVERY? AND WHAT MATERIALS HAVE BEEN DISCOVERED SINCE?}

Primavesi's successful rediscovery and historiographical reconstruction should be seen against the background of an increased interest in the contextual aspects of ancient papyri and ancient artifacts in general. Part of the documentation consulted by Primavesi, in particular the diaries of the Prussian Papyrus Project, held in the Berlin Museum, had been generally available to historians for some time and had even been partially published. However, Primavesi began his research with work on a Strasbourg papyrus containing fragments of Empedocles, and it is precisely in Strasbourg where most of the cartel's official documents had ended up. Without going into the details of this archival history, ${ }^{16}$ it is fair to say that reconstructing the outline of the entire organization and its major players was made possible only by combining the

14. See Fredrik Hagen and Kim Ryholt, The Antiquities Trade in Egypt 1880-1930: The H.O. Lange Papers ([Copenhagen]: Det Kongelige Danske Videnskabernes Selskab, 2016]).

15. For the press, see Holger Essler and Maria Hermes-Wladarsch, "Zur Erwerbung der Bremer Papyrussammlung und des Apollonios-Archivs," Archiv für Papyrusforschung und verwandte Gebiete 38 (2015): 433-34; the existence of a note verbale may be inferred from Primavesi, "Zur Geschichte," 181-82. Copies are kept in Berlin, Auswärtiges Amt, Politisches Archiv, R90137110.

16. See Primavesi, “Zur Geschichte,” 173-80. 
documentation preserved in both archives. The Strasbourg material was of vital significance, given that the bulk of the Berlin documents - including all minutes and correspondence concerning the Prussian Papyrus Project—-were stored in a central archive and lost during World War II.

Primavesi's 1996 publication did not aim to produce an exhaustive, detailed history of the organization. Given the loss of material, it would hardly have been possible at the time. It might come as a surprise that we should find ourselves in a much better position hardly twenty years later, mainly due to cataloging and digitization initiatives. Much more archival material is available online, and databases help to trace files, papers, and even single letters by chief actors involved. So, for instance, Wilhelm Schubart (1873-1960), who edited many literary papyri, including Sappho, Timotheus, Didymus and Euripides, acted as the cartel's general manager for most of its existence. As director of the Berlin papyrus collection, he was a key figure in the edition of new texts as well as in the acquisition of papyri all over Central Europe. Since all his papers burned in the 1943 bombing of his house in Berlin-Lichterfelde, his far-ranging activity is largely unknown. However, I was able to trace and collect about 250 of his letters written in this period, which will certainly allow me to reconstruct these crucial decades of his career.

Another source more readily accessible thanks to digitization is the newspapers of the time, which reveal that, when it came to the creation of historical collections, there was a lively public discussion in contemporary German politics, especially between federalists and unitarians. Whereas the federalists favored a wide distribution of the material creating many small collections at different universities and institutions in order to advertise the material and engage as many people as possible, the unitarians preferred to concentrate the collections in a limited number of places that had the scientific potential and financial means to become important centers of research. It comes as no surprise that the Berlin Committee adopted the unitarian view. The Munich Allgemeine Zeitung, which is now completely digitized by the Bayerische Staatsbibliothek, covered the entire discussion and also enables us to assess the different attitudes of the competitors as well as the power of lobbyism.

Finally — and not directly related to digitization - new archival material has come to the surface. First, and most importantly, the files of Ludwig Borchardt, mentioned above, were discovered in Cairo in 2007 and 2009. ${ }^{17}$ Since he was the only permanent German scientific representative in Cairo, he did most of the administration and

17. On the archive material, see Susanne Voss, Die Geschichte der Abteilung Kairo des DAI im Spannungsfeld deutscher politischer Interessen, vol. 1, 1881-1929 (Rahden: Marie Leidorf, 2013), 4. The discovery and cataloging are described in Thomas Gertzen, "Die Digitalisierung der Altakten \& 'Fragen an das Institut' - ausgesuchte wissenschaftliche Korrespondenzen aus den Archiven des DAI Kairo," Göttinger Miszellen 235 (2012): 5-12, esp. 6-7. 
accounting in Egypt. Thus, his papers and notes are even richer than what we would have had in Berlin, because he was dealing with virtually every German collector of his time and would be contacted by any colleague traveling to Egypt. His papers allow us to reconstruct the acquisitions made by Berlin and by other German collectors, acquisitions that led Berlin to found the cartel in order to avoid future competition.

Second, in the last decade, the private letters of the cartel's envoys to Egypt became available. For the first decade of the cartel, the Prussian Papyrus Project could afford to have a permanent representative in Cairo to purchase and dig for papyri. This position was held by Otto Rubensohn (1867-1964) from 1902 to 1907 and then by Friedrich Zucker (1881-1973) until March 1910. Both were at an early stage of their career and sent weekly letters to their families. With regard to such family documents, the crucial moment tends to arrive when the last person who knew the writer-usually a grandchild - is dying. In this case, the family decided to present the papers to public institutions and make them available for study. Not surprisingly, such private letters suggest a different picture of the whole enterprise than the official reports by revealing motivations, hypotheses, and details that would never come up in other sources. However, from a more narrowly scholarly perspective, such letters could also contain philological discussions and textual conjectures that might well anticipate or improve more recent results. Even when they do not provide new insights, they are equally important in determining the gaps and drawbacks of the writer's research.

In my opinion, these last points can be generalized and thus provide a rather promising outlook on future research about the history of knowledge of this period. Of course, not every letter believed to be lost will turn up, but if it does, it will most likely be in these years, as the third generation inherits the material they have no direct relationship to. Most of these writings will be out of copyright and immediately publishable. In addition to this, massive digitization initiatives generate new powerful tools for mass transcription and cross-referencing, thus enabling scholars to exploit these sources in manifold ways, both for the research and for the history of the discipline.

\section{WORKS CITED}

\section{ARCHIVAL SOURCES}

R 138392, R/901/37110, Politisches Archiv, Auswärtiges Amt, Berlin. Nachlass Karl Kalbfleisch 8, Universitätsbibliothek Gießen.

\section{PRINT SOURCES}

Braun, Maximilian, William M. Calder III, and Dietrich Ehlers, eds. 1995a. "Lieber Prinz": Der Briefwechsel zwischen Hermann Diels und Ulrich von Wilamowitz-Moellendorff (1869-1921). Hildesheim: Weidmann. 
1995b. Philology and Philosophy: The Letters of Hermann Diels to Theodor and Heinrich Gomperz (1871-1922). Hildesheim: Weidmann.

Calder, William M. III. 2003. "Aus dem Freund ein Sohn": Theodor Mommsen und Ulrich von Wilamowitz-Moellendorff, Briefwechsel 1872-1903. 2 vols. Hildesheim: Weidmann.

De Strycker, Emile. 1977. "Der Nachlaß von Hermann Diels.” Philologus: Zeitschrift für antike Literatur und ihr Nachleben 121:137-45.

Dieterich, H., and F. von Hiller. 1934. Usener und Wilamowitz: Ein Briefwechsel, 1870-1905. Leipzig: Teubner.

Ehlers, Dietrich, ed. 1992. Briefwechsel Hermann Diels, Hermann Usener, Eduard Zeller. 2 vols. Berlin: Akademie-Verlag.

Essler, Holger, and Maria Hermes-Wladarsch. 2015. "Zur Erwerbung der Bremer Papyrussammlung und des Apollonios-Archivs." Archiv für Papyrusforschung und verwandte Gebiete 38:433-81.

Fowler, Robert L. 1990. "Ulrich von Wilamowitz-Moellendorff." In Classical Scholarship: A Biographical Encyclopaedia, edited by W. W. Briggs and William M. Calder III, 489-522. New York: Garland.

Gertzen, Thomas. 2012. "Die Digitalisierung der Altakten \& 'Fragen an das Institut'-ausgesuchte wissenschaftliche Korrespondenzen aus den Archiven des DAI Kairo.” Göttinger Miszellen 235: $5-12$.

Hagen, Fredrik, and Kim Ryholt. 2016. The Antiquities Trade in Egypt 1880-1930: The H.O. Lange Papers. [Copenhagen]: Det Kongelige Danske Videnskabernes Selskab.

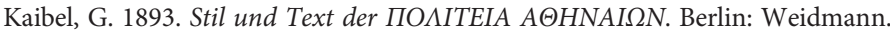

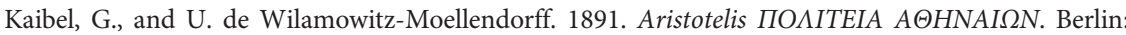
Weidmann.

Keil, B. 1892. Die solonische Verfassung in Aristoteles Verfassungsgeschichte Athens. Berlin: R. Gaertner.

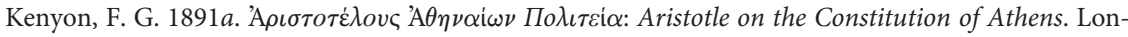
don: British Museum.

- 1891b. Classical Texts from Papyri in the British Museum: Including the Newly Discovered Poems of Herodas. London: British Museum.

- 1897. The Poems of Bacchylides: From a Papyrus in the British Museum. London: British Museum.

Müller, Wolfgang. 1957. "Papyruskunde.” In Das Institut für Griechisch-Römische Altertumskunde: Protokoll der Eröffnungstagung vom 23.-26. Oktober 1955, 87-93. Berlin: Deutsche Akademie der Wissenschaften.

Preisendanz, Karl. 1933. Papyrusfunde und Papyrusforschung. Leipzig: Karl W. Hiersemann.

Primavesi, Oliver. 1996. "Zur Geschichte des Deutschen Papyruskartells.” Zeitschrift für Papyrologie und Epigraphik 114:173-87.

Voss, Susanne. 2013. Die Geschichte der Abteilung Kairo des DAI im Spannungsfeld deutscher politischer Interessen, vol. 1, 1881-1929. Rahden: Marie Leidorf.

Wilamowitz-Moellendorff, U. v. Aristoteles und Athen. 2 vols. Berlin: Weidmann. 